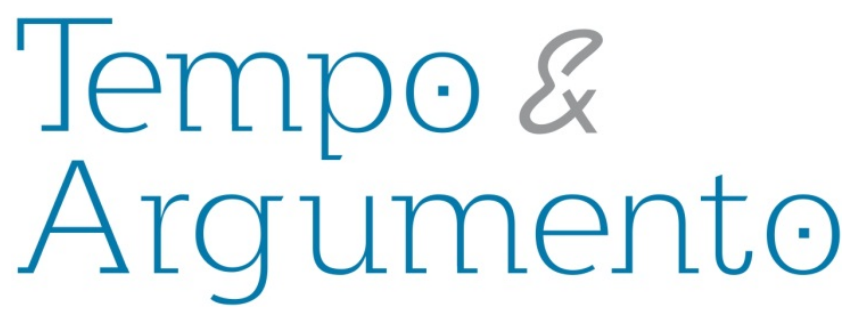

\title{
¿Cine + sociedad? El caso del documental político entre las narrativas revolucionarias y las democrático humanitarias
}

\begin{abstract}
Resumen
Este artículo está basado en una serie de cuestiones problemáticas atravesadas en mi tesis doctoral y último libro "Revolución y Democracia. El cine documental argentino del exilio (1976-1984)". El objetivo ha sido analizar el corpus de films documentales políticos argentinos realizados entre 1968 y 1989 para destacar tendencias formales y temáticas en relación con el contexto social. Las matrices ideológicas revolucionarias y democrático humanitarias constituyen el marco en el que los documentales son abordados como discursos de sobriedad con funciones sociales determinadas por el contexto de producción y las estrategias de realización. El análisis de los films se realizó mediante la separación en secuencias para detectar el modo de funcionamiento de procedimientos formales identificando continuidades y rupturas estéticas entre las obras divididas en tres conjuntos: 1968-1976, 19761984 y 1984-1989. Luego se procedió al reagrupamiento de las secuencias para extraer conclusiones sobre el uso de recursos formales en relación con las narrativas ideológicas marco, revolucionarias y democrático humanitarias. Desde hace más de doce años que participo en equipos académicos de investigación sobre historia y teoría del arte, de la cultura y, de manera específica, del cine. La misma antigüedad tiene el interrogante que moviliza mis estudios: ¿Cómo transmiten ideas los films documentales? O bien, ¿qué formas asume la relación cine y sociedad? Unas preguntas tan simples como esas no han encontrado más que respuestas parciales, difusas o escurridizas.
\end{abstract}

Palabras clave: Revolución. Democracia. Exilio. Cine Documental Argentino.

\author{
Javier Campo \\ Doctor en Ciencias Sociales (Universidad de \\ Buenos Aires). Investigador del CONICET. \\ Profesor de Estética cinematográfica (UNICEN). \\ Miembro del Centro de Investigación y Nuevos \\ Estudios sobre Cine (FFyL-UBA), del Instituto de \\ Investigaciones Gino Germani (FCS-UBA) y del \\ Departamento de Historia y Teoría del Arte \\ (Facultad de Arte, UNICEN). \\ ARGENTINA \\ javier.campo@cinedocumental.com.ar
}

\footnotetext{
Para citar este artículo:

CAMPO, Javier. ¿Cine + sociedad? El caso del documental político entre las narrativas revolucionarias y las democrático humanitarias. Tempo e Argumento, Florianópolis, v. 10, n. 23, p. 333 - 357, jan./mar. 2018.
} 


\section{Cinema + society? The case of the political documentary between the revolutionary and the democratic humanitarian narratives}

\section{Cinema + sociedade? O caso do documentário político entre as narrativas revolucionárias e as democrático humanitárias}

\begin{abstract}
This article is based on a series of problematic issues crossed in my doctoral thesis and last book "Revolution and Democracy. The Argentine documentary film of the exile (1976-1984)". The objective has been to analyze the corpus of Argentine political documentary films made between 1968 and 1989 to highlight formal and thematic tendencies in relation to the social context. Revolutionary and Humanitariandemocratic matrices constitute the framework in which documentaries are approached as discourses of sobriety with social functions determined by the context of production and strategies of realization. The analysis of the films was done by the separation in sequences to detect the formal procedures way of functioning to identify continuities and aesthetic ruptures between the works divided in three groups: 1968-1976, 1976-1984 and 1984-1989. Then the sequences was regrouped to draw conclusions about the use of formal resources in relation to ideological framework narratives, revolutionary and humanitarian. For more than twelve years I have participated in academic research teams on the history and theory of art, culture and, specifically, the cinema. The same antiquity has the question that mobilizes my studies: How do documentary films transmit ideas? Or, what forms does the relationship between cinema and society assume? Such simple questions as these have found only partial answers, diffuse or elusive.
\end{abstract}

Keywords: Revolution. Democracy. Exile. Argentine Documentary Film.

\begin{abstract}
Este artigo baseia-se em uma série de questões problemáticas percorridas na minha tese de doutorado e último livro "Revolução e Democracia". O documentário argentino do exílio (1976-1984)". O objetivo foi analisar o corpus de documentários políticos argentinos realizados entre 1968 e 1989 para destacar tendências formais e temáticas em relação ao contexto social. As matrices humanitárias ideológicas e democráticas revolucionárias constituem o quadro em que os documentários são abordados como discursos de sobriedade com funções sociais determinadas pelo contexto de produção e estratégias de realização. A análise dos filmes foi realizada por meio da separação em seqüências para detectar o modo de operação de procedimentos formais identificando continuidades e rupturas estéticas entre as obras divididas em três grupos: 1968-1976, 1976-1984 e 1984-1989. Em seguida, procedemos ao reagrupamento das seqüências para tirar conclusões sobre o uso de recursos formais em relação ao quadro, narrativas ideológicas revolucionárias e humanitárias democráticas. Há mais de doze anos participei em equipas de pesquisa acadêmicas sobre história e teoria da arte, da cultura e, especificamente, do cinema. A mesma antiguidade tem a questão que mobiliza meus estudos: como os filmes documentários transmitem ideias? Ou, que formas assume o filme e a sociedade? Perguntas simples, como essas, encontraram apenas respostas parciais, difusas ou indescritíveis.
\end{abstract}

Keywords: Revolução. Democracia. Exílio. Cinema Documentário Argentino. 


\section{La matriz de pensamiento revolucionario}

La matriz de pensamiento que se gesta desde mediados de los sesenta entre la intelectualidad y juventud, contiene múltiples elementos recurrentes en la historia argentina que interrelacionados demuestran que, como afirmaron Claudia Hilb y Daniel Lutzky en uno de los primeros estudios sobre el fenómeno insurreccional, los integrantes de la nueva izquierda reprodujeron un lenguaje ya establecido con anterioridad, en "una sociedad en la que el 'otro' era el enemigo” (citado en OBERTI y PITTALUGA, 2012, p. 159). Por un lado, la radicalización ideológica puesta en marcha desde fines de los sesenta gracias a las rebeliones críticas y violentas (los diversos “azos": Cordobazo, Rosariazo, Tucumanazo, Viborazo, etc.) y, por otro, la dureza progresiva con la que las dictaduras militares van a responder a ellas, extienden la creencia en la violencia como la forma para solucionar los conflictos y lograr transformaciones sociales. "El mito de la acción armada -según Ana Longoni-, la violencia, como “único camino”” se hace fuerte y rector (2007, p. 169). Por otra parte, y como destaca Hugo Vezzetti, entre 1969 y 1973 en la sociedad “crece la aceptación de las acciones de la guerrilla” (2009, p. 62). Según Pablo Pozzi y Claudio Pérez, "en los períodos anteriores, la izquierda contó con nutridos grupos de adherentes en todos los sectores sociales. Sin embargo, fue entre 1960 y 1990, que toda una generación se lanzó por el camino de la revolución social” (POZZI; PÉREZ, 2012, p. $\mathrm{XIII)}{ }^{2}$

Dentro de la "nueva izquierda", caracterizada aquí, se encontraban los cineastas que estaban teniendo sus primeras experiencias cinematográficas, pero también políticas, en la década del sesenta. La progresiva radicalización ideológica de los principales miembros de los dos grupos de cine militante más importantes resulta ejemplar del conjunto. Octavio Getino y Fernando Solanas (Cine Liberación), durante la realización de La hora de los hornos (1968) fueron acercándose al peronismo de izquierda, luego participando con realizaciones comprometidas de la onda expansiva del Cordobazo

\footnotetext{
${ }^{1}$ Acuerda, en un estudio más reciente, María Matilde Ollier: "el paradigma amigo/enemigo, el código binario que impregna la cultura política argentina en ese período", entiende a las disputas políticas menos como negociación que como guerra (2009, p. 16).

${ }^{2}$ Para estos autores las "expresiones y ciclos de la violencia política son un elemento central para analizar las dinámicas sociales y políticas que tensionan y caracterizan a una sociedad en pleno proceso de cambio" (Pozzi y Pérez, 2012, p. X).
} 
(en el caso de Getino) y entrevistando a Juan Domingo Perón para la realización de dos films, convirtiéndose en los representantes de su imagen cinematográfica (MESTMAN, 2007). Raymundo Gleyzer (Cine de la Base) comenzó su carrera realizando films etnográficos en los sesenta y abandonó ese tipo de cine cuando se demostró “insuficiente" para expresar los motivos de la pobreza. Para luego participar del Frente Antiimperialista por el Socialismo (FAS) y realizar los Comunicados Cinematográficos del Ejército Revolucionario del Pueblo (ERP).

El pasaje a la radicalización política de masas de jóvenes se produce cuando deciden ingresar a la izquierda revolucionaria: las organizaciones político militares como Montoneros, el ERP, las Fuerzas Armadas Peronistas o las Fuerzas Armadas Revolucionarias, entre otras. Ollier destaca que "ingresar a una organización política les permite salvar la brecha existente entre la creencia en la revolución social (radicalización ideológica) y la acción militante propia de un partido revolucionario (radicalización política)" (OLLIER, 2009, p. 19). De la consideración de la violencia como solución a la asunción de la violencia como camino personal, la conexión entre lo público y lo privado. A propósito de ello Ollier destaca una “doble subordinación”, de lo privado a lo político y de lo político a lo militar -algo ya profundizado, entre otros, por Pilar Calveiro (2001 y 2005)-. Subordinación que transformó en "militares" a los miembros de la izquierda revolucionaria que eran intelectuales, artistas y profesionales. Ejemplo de ello en el campo del cine son los casos de los directores Pablo Szir y Enrique Juárez, ${ }^{3}$ quiénes dejaron de filmar y pasaron a formar parte activa de Montoneros, empuñaron las armas, fueron secuestrados y desaparecidos. Vania Markarian, utilizando un concepto de Raymond Williams, considera que este pasaje era parte de la “'estructura de sentimiento' de la época, es decir, del conjunto de percepciones y valores compartidos que se manifiesta de modo privilegiado en el arte y la literatura" (MARKARIAN, 2012, p. 128).

Recorrer las distintas expresiones de la "violencia política” permite, para Pozzi y Pérez, "adentrarse en las tramas políticas latinoamericanas” (POZZI; PÉREZ, 2012, p. XII), en particular, la teoría del foco revolucionario, nutrida por los aportes teóricos y prácticos

3 El último film de Juárez fue Ya es tiempo de violencia (1969), mientras que Szir dejó inconcluso el largometraje Los Velázquez, basado en el libro de Roberto Carri (Isidro Velázquez, formas prerrevolucionarias de la violencia), luego de filmar intermitentemente entre 1971 y 1973. 
fundamentar la necesidad de un cambio revolucionario. Esas condiciones son puestas en imágenes en las primeras secuencias de La hora de los hornos (GETINO; SOLANAS , 1968), Ya es tiempo de violencia (1969), Argentina, mayo de 1969: los caminos de la liberación (Realizadores de Mayo, 1969), entre otros films que retroalimentaron a la matriz revolucionaria. Con respecto a las condiciones subjetivas, para Longoni, "las crea el foco a través de la acción. El foquismo guevarista [...] combinó un extremo voluntarismo y un gran subjetivismo" (LONGONI, 2007, p. 173-174). El camino de la acción a la teoría decanta en una "pura práctica fundante" de las acciones político revolucionarias, afirmándose en una identidad "antes que en un programa", destaca Hugo Vezzetti (VEZZETTI, 2009, p. 173).

Las narrativas revolucionarias para el análisis de la sociedad y su accionar sobre ella, "han durado lo que duraron las organizaciones y la cultura -dice Vezzetti-, el sistema de creencias, que sostenían esa estrategia” (VEZZETTI, 2009, p. 138). Esa configuración política y subjetiva fue "desmantelada" para dar paso a "una nueva era" que dejó de entender a la política como guerra para comprenderla como negociación (VEZZETTI, 2009, p. 127-138). La comprensión de la democracia constitucional fue modificándose ya desde el período del exilio para los ex militantes revolucionarios. Un nuevo sistema de creencias fue puesto en marcha.

\section{Los cambios en el exilio}

Luego del golpe de Estado, el escape del terror y la certificación de que la dictadura no iba a durar poco se producen revisiones ideológicas que marcarán las identidades de los actores. Norbert Lechner, analizando de forma general el caso de los intelectuales latinoamericanos, advierte que hay una "revisión biográfica [...] que

\footnotetext{
${ }^{4}$ Markarian recuerda una frase de Fidel Castro que resumía dicho llamado: "Quienquiera que se detenga a esperar que las ideas triunfen primero en las masas, de manera mayoritaria, para iniciar la acción revolucionaria, no será jamás revolucionario" (en Markarian, 2012: 77).
} 
fomenta una apreciación diferente de los procedimientos democrático-formales" (LECHNER, 1988, p. 29). Los intelectuales habían considerado a la democracia en el período anterior, como instrumento "burgués" manipulable, sólo funcional a los fines de los poderes imperiales constituidos. La revalorización de la democracia (léase "sistema democrático") se da por la necesidad “indispensable de instaurar 'reglas de juego"” (LECHNER, 1988, p. 29). Y es, justamente, en el exilio donde se da, según el mismo Lechner, una circulación internacional de los intelectuales que les permite conocer y debatir experiencias democráticas no revolucionarias, pero tampoco opresivas o autoritarias, sino tendientes al establecimiento de políticas públicas progresistas. La crisis de la fe revolucionaria encontró a los exiliados con otras experiencias que favorecieron un proceso de revisión ideológica crítica, como asimismo de producción de reflexiones tendientes a la tolerancia política.

Esta nueva izquierda intelectual "se opone a su anterior posición de 'antagonista del poder"”, de modo que ciertas imágenes, como la del intelectual orgánico, se desvanecían para dar paso a la participación en los debates que hacen al sistema político democrático parlamentario. "Se desdibuja un pensamiento ansioso por predeterminar el sentido de la historia. Ahora se reconoce el carácter plural, multifacético y/o concertado que pueden presentar las luchas políticas y las sociales, y un nuevo relato ocupará el lugar que antaño tenía la idea de revolución" (LESGART, 2004, p. 180). Ya no se comprenderá la política en términos de guerra, se censurará la insurrección y se respetará la dimensión procedimental ante otras como la consecución de la igualdad. La democracia como un fin en sí mismo se vuelve un tópico recurrente de los discursos esgrimidos en su defensa. Ya no como medio intercambiable con otros si demuestra su inoperancia para solucionar problemas sociales, sino como sistema de derechos y obligaciones siempre perfectible. Según Lechner, "vuelve a primar el crítico por sobre el profeta y la vocación política ya no se apoya en un compromiso de militancia partidista" (LECHNER, 1988, p. 32). ${ }^{5}$

Los ex miembros de la izquierda revolucionaria cumplieron un "papel central" en el exilio, según Ollier (2009, p. 172), debido a que vincularon al movimiento local de

\footnotetext{
${ }^{5}$ También Lechner destaca que el signo de este nuevo tiempo ya no es la política del aniquilamiento del adversario, sino "el reconocimiento recíproco", contraponiendo una "lógica política" a la "lógica de la guerra" (1988, p. 33).
} 

planificada y sistemática” (JENSEN, 2011, p. 3), luego de 1977 (año en que se produce la conformación de las Madres de Plaza de Mayo y se publican las primeras solicitadas reclamando por los desaparecidos) los exiliados presionaron con decisión al régimen, haciendo visibles sus denuncias gracias a organismos internacionales de relativo poder, como Amnesty International y la Comisión Interamericana de Derechos Humanos.

El exilio argentino "debe entenderse -destaca Pablo Yankelevich- como un proceso colectivo pero desarrollado a partir de la sumatoria de acciones individuales; no se trató de un fenómeno organizado" (YANKELEVICH, 2007, p. 209). Gran parte de los exiliados no recibieron un status especial, salieron de la Argentina y entraron a otros países en calidad de turistas, no permanecieron en un mismo destino por mucho tiempo y muchos de ellos no volvieron a radicarse en la Argentina con posterioridad. Por ello es que el exilio argentino presenta dificultades para su cuantificación, debido a su “naturaleza misma (clandestina)” (YANKELEVICH, 2007, p. 209). Sí, podemos decir que se trató de un fenómeno masivo, múltiple y heterogéneo. Se estima que la cifra más certera contabilizaría entre 300.000 y 500.000 exiliados para el período 1975-1983, lo cual constituiría entre el $1 \%$ y el $2 \%$ de la población argentina en ese momento. Porcentaje similar al del caso chileno pero alejado del uruguayo, país que tiene las estimaciones más altas para Latinoamérica: aproximadamente el 10\% de la población. El período fuerte de salidas de la Argentina fue 1976-1978, aunque hasta 1983 se siguieron produciendo emigraciones por goteo. Por otra parte, como destaca Yankelevich, igualar el exilio argentino del 1976-1983 a otros exilios históricos argentinos ${ }^{6}$ sería "empobrecer la mirada", debido a que éste no se restringió a personalidades intelectuales y políticas, sino que hubo "múltiples exilios desarrollados sobre una variedad de motivos y de prácticas políticas y sociales" (YANKELEVICH ,2007, p. 215). Aunque estuvo integrado en buena parte por profesionales, gente del mundo de la cultura, políticos o sindicalistas; la clase

\footnotetext{
${ }^{6}$ Como los de José de San Martín, Juan Manuel de Rosas, Domingo Faustino Sarmiento, Juan Bautista Alberdi o Juan Domingo Perón, por ejemplo.
} 
antagonismos que se reprodujeron en el interior de todos los organismos creados por los exiliados" (YANKELEVICH, 2007, p. 220). ${ }^{8}$

En el exilio se dio, como destaca Emilio Crenzel, una profunda transformación de las narrativas revolucionarias en su opuesto: las narrativas humanitarias (CRENZEL, 2008, p. 38-51). De la justificación del uso de la violencia política al apego hacia lo legal, del desprecio por la Constitución como letra muerta que es usada en favor de los intereses de la burguesía, a la militancia democrática en favor del afianzamiento de la República. De la acción por la lucha revolucionaria hacia la defensa de los derechos humanos, las narrativas viraron de manera brusca en el exilio, dando cuenta de una rotunda derrota política de las organizaciones armadas (CRENZEL, 2008, p. 45).

Como destaca Vania Markarian el cambio de coyuntura internacional repercutió de manera profunda entre los exiliados sudamericanos:

Inicialmente críticos de las organizaciones de derechos humanos por no atacar las causas estructurales de la situación imperante en sus países, estos exiliados fueron adoptando paulatinamente la retórica política de estas organizaciones y planteando sus reivindicaciones en el lenguaje de los derechos humanos (MARKARIAN, 2004, p. 1).

Markarian hace un recorrido por los tópicos configurados y esgrimidos por los militantes en el exilio que van conformando una narrativa humanitaria más bien homogénea y sin grandes diferencias entre las diferentes nacionalidades: se comienza a interpelar a los muertos y desaparecidos como "víctimas", utilización discursiva "que no tenía antecedentes entre los militantes de izquierda" (MARKARIAN, 2004, p. 14); se

\footnotetext{
7 Para reponer los datos de conformación del exilio véanse los artículos de Victoria Basualdo ("Una aproximación al exilio obrero y sindical”) y, especialmente, de Silvina Jensen y Pablo Yankelevich (“México y Cataluña: el exilio en números") presentes en Jensen y Yankelevich (comps., 2007). Asimismo, Jensen (2010).

${ }^{8}$ Al mismo tiempo Jorge Luis Bernetti y Mempo Giardinelli (2003) destacan como un elemento importante las divisiones entre los exiliados que dificultaron la organicidad de las agrupaciones.
} 
aportan evidencias testimoniales, "pero evitando apelar a cualquier tipo de identificación con sus ideologías o concepciones políticas" (MARKARIAN, 2004, p. 10); y se describen las prácticas represivas ya no con el propósito de valorizar el coraje de sus compañeros secuestrados, sino "con la intención de sensibilizar a vastas audiencias" (MARKARIAN, 2004, p. 13).

\section{La matriz de pensamiento democrático humanitaria}

Las narrativas democrático humanitarias se caracterizan por su confianza en los testimonios anclados en el cuerpo como un signo de verdad absoluta e incontrastable, destaca Thomas Laqueur (LAQUEUR, 1996, p. 177). Luego de hacer un recorrido por la producción de las mismas en la novela realista y el discurso médico, Laqueur dice que esas "montañas de hechos", elevadas por las narrativas humanitarias a una categoría superior de evidencia, "despiertan pasiones de misericordia que pueden implicar (eventualmente) un deber ser" (LAQUEUR, 1996, p. 194-204). La elaboración de estas narrativas busca una asunción de responsabilidad, una conminación a la movilización, a la acción en favor de la modificación de las condiciones que propiciaron el sufrimiento inflingido a ese cuerpo, vivo o muerto, que testimonia.

Con el ocaso de la dictadura -afirma Vezzetti-, se inaugura una nueva constelación de sentidos dominada por el acontecimiento mayor, el terrorismo de Estado: la presencia de las víctimas relega al olvido las estampas combatientes. [...] En cuanto predominaba la solidaridad con las víctimas y el nuevo discurso sobre los derechos humanos, se opacaba o directamente se impugnaba la narrativa de los combates por la revolución (VEZZETTI, 2009, p. 69-70).

El compromiso pasó de la entrega absoluta a la política a una movilización acotada y concreta. Como indica Marina Franco, esto no significó una despolitización, sino el pasaje a nuevas “formas de la acción política” (FRANCO, 2008, p. 308). “Desde su punto de vista -dice Markarian-, los derechos humanos suponían un cambio en su concepción de la actividad política: desde un lenguaje de heroísmo revolucionario e identificación ideológica a un discurso que apelaba a razones "humanitarias"” (MARKARIAN, 2004, p. 14). 
Las narrativas humanitarias echadas a andar desde el exilio, que se constituyeron en letra de las denuncias por los desaparecidos, fueron homogeneizando los discursos sobre la violencia estatal. En efecto,

La clave revolucionaria - destaca Crenzel - con la cual había sido denunciada la represión política y las propias desapariciones antes del golpe de 1976 fue paulatinamente desplazada por una narrativa democrático humanitaria que convocaba, desde un imperativo moral, a la empatía con la experiencia límite sin historizar el crimen ni presentar vínculos entre "el ejercicio del mal, sus perpetradores y sus víctimas" (CRENZEL, 2008, p. 44).

Dicha homogeneización decantó inclusive en la inversión de los fundamentos e ideales de la lucha revolucionaria anterior, hasta el punto de describir a los desaparecidos como luchadores por la democracia y no por su compromiso con la revolución (CRENZEL, 2008, p. 48). Por su parte, Pablo Giussani destacaba que había una "total coincidencia entre los familiares de los desaparecidos en no reconocer la militancia que los convirtió en objeto de la represión" (GIUSSANI, 1986, p. 13). Y, analizando testimonios de ex militantes, Alejandra Oberti y Roberto Pittaluga afirman que ese fue "un silencio estratégicamente dictado por la necesidad de dar cuenta de los crímenes de la dictadura" (OBERTI; PITTALUGA, 2012, p. 88).

Durante las dictaduras latinoamericanas y luego de su finalización, una de las premisas de las redes transnacionales de derechos humanos era no presentar la trayectoria política de los desaparecidos, de los denunciantes ni de la violencia política, basarse únicamente en lo aberrante e ilegal del secuestro, tortura, desaparición y muerte. El anclaje del discurso de matriz democrático humanitaria estaba en recalar en el carácter de violación a los derechos humanos, cualquiera fuese la trayectoria de los desaparecidos (que ya no eran interpelados como militantes o compañeros, sino como víctimas ${ }^{9}$ ). En este contexto sociopolítico que lleva de narrativas de matriz revolucionaria a aquellas democrático humanitarias, el cine documental del subcontinente se caracterizó por la realización de films de retórica política que abrevaron en estas matrices.

\footnotetext{
9 “La 'teoría de los dos demonios' -afirman Oberti y Pittaluga-, así como las prácticas y nociones primeras de la mayoría de las organizaciones de derechos humanos sobre la necesidad de reforzar el carácter de 'victimas' conspiraron en términos desiguales para que no se hable de su militancia" (2012, p. 30-31).
} 
Si bien no todo ha sido documental político en la historia cinematográfica de América Latina, según Paulo Antonio Paranaguá (2003, p. 16), el documental político obtuvo un "estatus privilegiado" tanto entre las corrientes cinematográficas renovadoras como entre los films sociales y comprometidos desde fines de la década de 1950 (BURTON, 1990, p. 6). "Los realizadores comprometidos socialmente -continúa Julianne Burton- han considerado al documental como su herramienta principal en la búsqueda y el descubrimiento de las realidades sumergidas, negadas y devaluadas" (BURTON, 1990, p. 6). Para Burton, el contexto político en que surge explicapor qué: “El documental, aún no habiendo surgido con intereses políticos firmes, adquiere dimensión política" radical (BURTON,1990, p. 19). Por otra parte, para Michael Chanan, el documental latinoamericano "despega junto con un fermento social en países en los que las convulsiones políticas son frecuentes" (CHANAN, 2007, p. 203). En lo referido al cine latinoamericano no es necesario que aquí se desarrolle un recorrido por teorías e historias, la bibliografía de referencia es numerosa (SCHUMANN, 1988; PARANAGUÁ, 2003; ELENA y LÓPEZ, 2004; MARTIN, 1997; PICK, 1993; FLORES, 2013). Es importante focalizar brevemente sobre el segundo concepto, el de "cine político", disperso en obras, en general, no sistematizado.

\section{Documental, política y funciones sociales}

De un rastreo no muy exhaustivo por la historia del cine documental surge como evidente el hecho de que el documental ha sido uno de los vehículos principales del discurso y la retórica política y que, por otra parte, un porcentaje significativo de los films documentales han presentado conceptos, problemáticas y posturas políticas de formas más o menos sutiles. Según Bill Nichols se trata "del género más explícitamente político" (NICHOLS, 1997, p. 15) y para Michael Chanan "la política está en sus genes" (CHANAN, 2011, p. 45). Precisamente, es éste último quien desarrolla uno de los estudios más profundos sobre este vínculo. Chanan destaca que "el documental es más una fuerza moral y política que sólo una práctica artística" (CHANAN, 2007, p. 29). Sin esfera pública proyectada, el documental no funcionaría de manera apropiada ni respondería a sus atributos sociales. Chanan afirma que "el documental es político por naturaleza [...] 
porque invita a la sociedad a observar a sus propios individuos y sus propias preocupaciones [...], se dirige al espectador en cuanto ciudadano, en cuanto miembro de un colectivo" (CHANAN , 2007/2008, p. 94). Esta noción de "lo político" resulta amplia y no se remite sólo a los films militantes, sino que incluye en su seno también a los documentales sobre conflictos medioambientales, por ejemplo.

La tensión entre el interés público y la cuestión particular de una problemática social es lo que Jonathan Kahana llama "trabajo de inteligencia", gracias al cual el “documental social” adquiere su poder, “de su desplazamiento alegórico de los detalles particulares al plano de las significaciones generales" (KAHANA, 2008, p. 26). Lo “ejemplar”, según Kahana, se encuentra de manera frecuente en los documentales sociales en la intersección generada por ese "trabajo de inteligencia”. Lo ordinario, el caso, es siempre ejemplar gracias al desplazamiento alegórico (KAHANA, 2008, p. 26).

Por su parte, tratando de responder si existe una conexión entre el cine documental y "la acción social o el cambio social”, Jane Gaines elabora el concepto de “mímesis política” (GAINES,1999, p. 84-90). Emparentando su formulación con el concepto de "trabajo de inteligencia" de Kahana, la autora destaca que la mímesis política se refiere a, y “comienza” con, los cuerpos. "Es la relación de los cuerpos en dos lugares: la pantalla y la audiencia" (GAINES ,1999, p. 90). La mímesis política propulsada por los films documentales políticos indica que un cuerpo (el de la pantalla) señala al otro “que hay que hacer cosas" (GAINES, 1999, p. 90). Gaines se inspira en la categorización creada por Linda Williams para dividir a los géneros que: “'hacen que el cuerpo haga cosas' (el terror hace que gritemos, el melodrama que lloremos y el porno que 'acabemos')" (GAINES, 1999, p. 90); y agrega en ese grupo al documental político que, en definitiva, completa su denominación con la acción política de la audiencia.

La noción de "documental comprometido", utilizada por Thomas Waugh en su pionera compilación de estudios sobre el documental político, se aplica a los films “ocupados en transformar la realidad [...] El documental es un medio privilegiado para los artistas comprometidos y su público, y una fuente prioritaria para el activista político" (WAUGH, 1984, p. XIV-XIX). En esa línea, Patricia Zimmermann concibe a la cámara como “una membrana, una superficie permeable a través de la cual las relaciones entre 
realizador y sujetos pasan y se mezclan" (ZIMMERMANN, 2000, p. 95). La visión de estos tres autores representativos de los estudios del documental político (GAINES,1999 WAUGH,1984 y ZIMMERMANN,2000) es condensada por ésta última al destacar que "las fronteras entre el realizador y los sujetos, los agentes activos y su representación, se disuelven en un más fluido y permeable constructo" (ZIMMERMANN, 2000, p. 95). ${ }^{10}$

En el final, Gaines responde a la pregunta inicial:

La razón por la cual se usa el documental para promover objetivos políticos es debido a que su estética de la similitud establece una continuidad entre el mundo de la pantalla y el de la audiencia, donde el espectador es llamado a intervenir en ese mundo que está tan cerca (GAINES, 1999, p. 92).

No es necesario recordar aquí que un fotograma no es una pintura, el vínculo con lo real es privilegiado en el cine; y lo es de una manera más privilegiada en el documental, que construye su estatuto como resultado de su vínculo ontológico con lo real.

En cuanto a las características formales del documental político en general, Patricia Zimmermann escoge remarcar el cariz expositivo de los films comprometidos por estar en busca de argumentar para persuadir, dejando de lado la reflexión sobre sus mismas representaciones (ZIMMERMANN, 2000, p. 103). Es decir, no se explicita una desconfianza en la representación, todo lo contrario, los documentales políticos hacen descansar sus representaciones en el hecho dado de que existe un vínculo indicial entre lo real y las imágenes y sonidos presentes en el film. En este sentido, el trabajo retórico de los documentales es una de las funciones más aceitadas, es "un estilo de cine que hace argumentos sobre el mundo para cambiarlo y movilizar a los espectadores" (ZIMMERMANN, 2000, p. 104). El teórico que más ha desarrollado este aspecto, aplicado al cine documental en general, ha sido Bill Nichols. Para él la retórica "es un medio a través del que el autor intenta transmitir su punto de vista al espectador de un modo persuasivo" (NICHOLS, 1997, p. 181). Si bien el procedimiento formal predilecto ha sido

\footnotetext{
${ }^{10}$ Zimmermann otorga numerosos ejemplos de ello, afirmando en todos los casos militantes analizados que "la cámara está clavada en el punto de vista de los sujetos [...] El film entero nos deposita en el terreno con los activistas" (2000, p. 96).
} 
históricamente la voz over, Nichols destaca que los demás elementos del discurso son también utilizados para la argumentación retórica.

Volviendo a las definiciones, es posible decir que existe en la bibliografía de referencia el reconocimiento de que tanto se puede sostener una postura restrictiva para dirimir qué film es político o no tenerla en absoluto. En este segundo caso, todo film es político "porque tiene una dimensión política -afirma Gustavo Aprea-, observable a partir de su forma de presentar los personajes, los vínculos que establecen entre ellos y la sociedad en que se desarrolla la historia junto con el modo en que aceptan o cuestionan las relaciones de poder" (APREA, 2007, p. 94). Pero, al mismo tiempo que se advierte esto, los investigadores remarcan que no resulta productiva dicha conceptualización (GETINO y VELLEGGIA, 2002, p. 16; PIEDRAS, 2009, p. 44). Por ello algunos se han abocado intermitentemente a tratar de marcar las fronteras del cine político mirando hacia adentro y afuera. Octavio Getino y Susana Velleggia afirman que es un cine contrahegemónico con "voluntad de cambio social y cultural" (GETINO y VELLEGGIA 2002, p. 16). Por ese motivo, está caracterizado por "un fuerte descentramiento del propio campo que torna al cine conscientemente permeable a las condiciones extracinematográficas" (GETINO y VELLEGGIA, 2002, p. 18). Esto no significa que necesariamente "film político" quiera decir "de intervención política”, sino que la noción implica la representación de cuestiones del mundo social desde un punto de vista político. Es decir, el cine político siempre es: "Un cine del presente, incluso cuando hable del pasado", tal como afirma Christian Zimmer (PIEDRAS, 2009, p. 57). En algunas ocasiones, los films son realizados para favorecer la transformación de las estructuras de poder, en otros, para hacer conocer la voz de los marginados; pero en todos los casos el film político pretende que el espectador reflexione (sobre el presente).

\section{El caso argentino}

El cine documental político argentino (1968-1989) tuvo diferentes funciones sociales. Según Michael Chanan, el cine documental, sobre todo el de vertiente política (militante o crítico por igual), vincula sus propósitos con los de la "sociedad" (CHANAN, 
2007/2008, p. 92). Es decir, éste cine desempeña diversas funciones sociales partiendo de sus imágenes, sonidos y palabras. Esta fusión entre propósitos del film documental político y la sociedad en la que es producido y circula (y las influencias en ambas direcciones) es fundamentada por diferentes teóricos, aunque sin haber producido análisis de los films en los que se visualice la operatoria de esas diversas funciones sociales. Aunar el estudio social con el análisis fílmico, partiendo desde los documentales ha sido el objetivo de mi investigación doctoral y libro. Algunos films fueron más abordados en la bibliografía de referencia, los del período 1968-1976 y otros producidos en la transición democrática (1984-1989). Por ello, he dedicado un amplio espacio al cine documental político realizado en el exilio (1976-1984) mediante un estudio sistemático de las correspondencias de los procedimientos formales y las narrativas sociales dominantes. Para ello, resultó de suma importancia focalizarse en tres conceptos técnicos: voz over, material de archivo y testimonio. Mediante las diversas utilizaciones de los mismos las perspectivas formal y abierta, pudieron ser caracterizadas para configurar el panorama formal y temático del cine documental político argentino del período 1976-1984.

Un porcentaje importante de investigadores indican que el cine documental se dirige a sus espectadores en tanto ciudadanos activos de una sociedad. Definición de la que no puede ser marginado el cine documental político argentino. Con pretensiones de intervención política o socialmente críticos, todos los films buscaron a través de sus narraciones llamar a la reflexión política de sus espectadores. Michael Chanan indica que la mayor parte de la historia del documental se puede entender al mismo tiempo como “el campo de batalla de la verdad social e histórica, y esta es una de las razones principales por las cuales la gente hace documentales (políticos)" (CHANAN, 2007, p. 2223). El agregado entre paréntesis es absolutamente necesario debido a que la interpelación al espectador no implica en todos los casos un llamado de atención sobre cuestiones sociales que hacen al bienestar común. Los documentales etnográficos, musicales, sobre la naturaleza o deportes no se ubican necesariamente en ese "campo de batalla".

De manera global, las narrativas revolucionarias y humanitarias fueron las que se dividieron la primacía de creación de sentidos entre 1968 y 1989 en la Argentina. Y como 
tales estuvieron presentes en la sociedad en que se produjeron las representaciones documentales de función social política en el período mencionado. No sólo eso, en el análisis de los films, con todas las excepciones ya remarcadas, hemos destacado esas narrativas como matrices mediante las cuales los films documentales políticos argentinos elaboraron sus discursos.

\section{Continuidades y rupturas en el documental político argentino del período 1968-1989}

¿Es posible vincular formas cinematográficas con contextos sociales? En principio, más allá de algunos elementos disonantes destacados en el análisis, he encontrado unidad en cada uno de los períodos cinematográfico políticos. Sin embargo, considerando que el quiebre formal, temático y de objetivos se da promediando el exilio ya no habría tres períodos bien delimitados (1968-76, 76-84 y 84-89), sino dos grandes bloques que, teniendo como punto de no retorno el bienio 1978/1979, concentran dos tipos de producciones cinematográficas de diferente signo político y formal.

Entre los elementos ideológicos persistentes entre 1968 y 1989 presentes en las estructuras narrativas de los films, encontramos la afirmación de que la violencia siempre ha sido desatada por "ellos". Los antagonistas (léase “oligarquía”, clase política y militares "proimperialistas" en los films militantes de la primera época; o militares y civiles cómplices en los documentales realizados desde fines de los setenta) siempre estuvieron, y estarán, en la otra vereda porque, en los films, el pueblo somos "nosotros". Los realizadores erigen sus relatos como manifestación genuina de expresión de la voz del “pueblo”. El pueblo querrá “revolución” (antes de 1978/1979) o “democracia” (después) siempre en línea con el pensamiento expresado por los directores en imágenes, sonidos y palabras. Por otro lado, es constante el uso de material de archivo para favorecer la utilización de fragmentos del pasado que justifican las acciones y explicaciones para el presente. En general, las imágenes y sonidos del pasado ilustran el discurso para la acción sobre el presente, fundamentan la retórica del narrador y llevan la voz over adosada a sí. 
En cuanto al primer grupo de documentales, los realizados entre 1968 y 1976, si bien es el período en que se hace un uso más variado de procedimientos estéticos (animación, experimentación por montaje discursivo e intertítulos son utilizados, a diferencia de lo que ocurre en los otros dos períodos), prima el dominio de la voz over de un narrador omnisciente. Con La hora de los hornos (GETINO y SOLANAS , 1968) como modelo, los films militantes propondrán la violencia revolucionaria como solución al cuadro de situación planteado, tal como lo destacan los estudios ya citados en el primer capítulo para las organizaciones de izquierda del período (VEZZETTI, 2009; OBERTI y PITTALUGA, 2012; OLLIER, 2009; LONGONI, 2007). El objetivo siempre pretende ser buscado de buena forma pero, debido a que "ellos" inauguraron la violencia y aún la avivan al "pueblo" no le quedará otra forma más que la misma técnica. Los realizadores repiten al unísono la frase de María Antonia Berger, presente en Ni olvido ni perdón (1973): "Somos pacifistas, pero si no nos dejan otra vía..."

Pero no todos los elementos destacados en el análisis de los films realizados entre 1968 y 1976 van en el sentido de ser considerados dentro del espectro demarcado por la Perspectiva formal y el polo Revolución. Los dos grupos de cine militante más importantes y productivos del período (Cine Liberación y Cine de la Base) también tienen en su haber realizaciones no tan convencidas de que el único camino sea la revolución presentada con una voz over autoritativa. Muerte y pueblo (JUÁREZ,, 1969), El camino hacia la muerte del viejo Reales (VALLEJO, 1971) y Me matan si no trabajo y si trabajo me matan (Cine de la Base, 1974) son films que presentan un amplio uso de los testimonios, secuencias de observación y discursos que ponen en cuestión que la única solución a los problemas sociales se encuentre por el camino de la lucha armada. Ya es tiempo de violencia (1969), Informes y testimonios: La tortura política en la Argentina 1966-1972 (1973) y Cerro de Leones (GAUNA, 1975) contienen llamados al respeto por los "derechos humanos" en algunas escenas. Otras "anomalías" en el período derivan de films que carecen de voces: Olla popular (Cine Liberación, 1968) y Marcha sobre Ezeiza (1973) solo tienen imágenes propias con música extradiegética. Excepciones que, sin embargo, 
permiten afirmar la regla general para el conjunto del período 1968-1976: estos procedimientos formales y apelaciones discursivas no se presentan en forma sistematizada, sino sólo en algunas secuencias; en cambio sí lo hace la voz over narrativa que canaliza los discursos de los films hacia la fundamentación de la "necesaria" revolución.

En el exilio se produce el quiebre formal, temático y retórico más importante del cine documental político argentino. Mientras en los dos primeros años se realizan films siguiendo estrategias similares a las del período anterior llamando a la lucha armada (inclusive enmascarando el hecho de que los documentales se han realizado enteramente en el exterior). Desde 1978 se presentan films en línea con las nuevas formas de denuncia de los organismos de derechos humanos -estudiadas por Jensen (JENSEN, 2010) y Franco (FRANCO, 2008), entre otros ya repasados-. El análisis desarrollado permitió observar correspondencias entre narrativas y procedimientos formales regulares. Del ingente uso de la voz over a la inclusión de voces testimoniales autobiográficas (de los realizadores) o biográficas en in, de familiares y detenidos-aparecidos. De la profusa utilización del archivo a su casi completa eliminación en algunos films en los que gobierna en soledad el testimonio in de los implicados en casos de violencia represiva. Luego de este quiebre se obvian las menciones a organizaciones guerrilleras y la militancia de los desaparecidos no es aludida. Una nueva estrategia judicial de las organizaciones de derechos humanos está naciendo (CRENZEL, 2008; MARKARIAN, 2004; OBERTI y PITTALUGA, 2012).

Debido, justamente, a que no es posible una caracterización total, sino partida, del bloque cinematográfico político 1976-1984, lo que podemos detectar como excepciones o “anomalías" son el anuncio de una nueva estética y voluntad política. En la frontera 1978/1979 se presentan sincretismos, en Esta voz... entre muchas (RíOS , 1979) ${ }^{11}$ hay apelaciones, de testimoniantes, sobre la "moral revolucionaria” aún en alto y denuncias contra el sistema capitalista (dos elementos típicos de las narrativas revolucionarias

\footnotetext{
${ }^{11}$ En 1979 en México Humberto Ríos produjo el primer film testimonial en que familiares de desaparecidos y asesinados denunciaban lo que estaba sucediendo en la Argentina, en Esta voz... entre muchas. El film ganó el premio Coral de Documental en el Primer Festival de Cine Latinoamericano de La Habana (1979), junto a Las AAA son las tres armas (Cine de la Base, 1977) y otros sobre el Cono Sur.
} 
anteriores); mientras que en Resistir (CALINKI,- CEDRÓN, 1978) ${ }^{12}$ y Persistir es vencer (Cine de la Base, 1978), ${ }^{13}$ dos films-comunicados de las organizaciones revolucionarias más importantes, hay llamados al respeto por los derechos humanos y pedido de tregua para restaurar el sistema democrático (dos elementos típicos de las narrativas humanitario democráticas posteriores).

En los documentales políticos sobre violencia represiva realizados entre 1984 y 1989 las certezas van reemplazándose por las dudas. Esto está vinculado a la utilización de los testimonios que dominan la pantalla, ocluyendo la expresión directa de la palabra de los realizadores y debido a que son montadas intervenciones de diferente cuño, que en algunos casos discuten entre sí sobre los motivos de la violencia represiva o las consignas de la lucha por la justicia. La introducción de la utilización del video en algunos de estos films permitió que los planos tuviesen mayor duración para la captura de los testimonios más sensibles.

Con algunas pocas y difusas apelaciones a la militancia política de los setenta, las “anomalías" entre este conjunto de documentales se corresponden con la presencia de voces over o testimonios unilaterales: los procedimientos formales de La república perdida 2 (PÉREZ, 1986) son extemporáneos por su férrea muestra de autoridad de los narradores y, por otra parte, No al punto final (DENTI, 1986) y A los compañeros la libertad (CÉSPEDES, y GUARINI, 1987) presentan testimonios que no delinean diversidad de puntos de vista, de perspectiva formal antes que abierta.

Para el análisis de los documentales políticos argentinos ha sido utilizada la conceptualización operativa de Carl Plantinga de perspectivas formal y abierta (PLANTINGA, 1997). Las mismas han sido relacionadas con los polos narrativos contrapuestos en uno y otro extremo: el revolucionario y el democrático. Mientras en los documentales que están construidos apelando primordialmente a narrativas revolucionarias se presentan certezas transmitidas mediante la autoridad de la voz over con el uso de material de archivo, lo cual constituye marcas definitorias de perspectiva

\footnotetext{
${ }^{12}$ En Roma Jorge Cedrón, bajo el seudónimo Julián Calinki, realizó una larga entrevista a Mario Eduardo Firmenich como material fundamental para Resistir (1978).

${ }^{13}$ Fue un cortometraje realizado por el grupo Cine de la Base, y registrado por Jorge Giannoni y Alvaro Melián en Roma, en ocasión de una reunión del Buró político del PRT-ERP.
} 
formal; en los films de narrativa humanitaria-democrática la presentación de testimonios y secuencias de observación construyen relatos reflexivos, pasibles de ser englobados dentro de una perspectiva abierta. Mientras que las películas que promueven la "revolución" conservan la fortaleza de conceptos transmitidos, aquellas que valorizan las instituciones democráticas ya no entienden a la política como guerra, dando lugar al debate de puntos de vista. Aunque sin absoluta unanimidad (atendiendo a las aquí llamadas "anomalías") los films realizados entre 1968 y 1976 pueden ser caracterizados como de Perspectiva formal, más cercana al polo Revolución, y los realizados entre 1984 y 1989 de Perspectiva abierta, definidos próximamente al polo Democracia. El período en el que se da un quiebre estético y político, el exilio 1976-1984, sigue la línea del período anterior hasta 1978/1979 y luego la que dominará al documental político hasta 1989.

\section{Elementos dispersos para una historia del cine documental argentino}

El caso del cine documental político argentino nos arroja elementos contundentes para discutir dos ideas relacionadas, que han sido aceptadas para caracterizar al cine documental político en general. Para Patricia Zimmermann, la estética dominante del documental político es la expositiva, este tipo de cine no deja brechas por las cuales pueda filtrarse la crítica interna a sus representaciones (ZIMMERMANN, 2000, p. 103). Por otro lado, Brian Winston afirma que los realizadores "radicales" son directos y explícitos, no dejan lugar a la reflexión o las dudas que puedan llegar a abrigar los espectadores, las despejan, son didácticos (WINSTON, 1995, p. 79). Pues bien, no todo el cine documental político argentino puede ser catalogado bajo estas generalizaciones. No podemos obviar lo que de cierto tienen estos conceptos, sin dudas una parte del documental político es acrítico con sus representaciones y "didáctico". Pero los procedimientos formales que llevan en sentido contrario, puestos en funcionamiento desde la primera obra, indican una tensión que no supone descabellado considerarlos propios de una Perspectiva abierta: las convocatorias a los espectadores en la diégesis de La hora de los hornos, los collages auditivos y visuales presentes en ese film y en Ya es tiempo de violencia, la palabra autobiográfica en los films de Gerardo Vallejo y Carlos Echeverría (Juan, como si nada hubiera sucedido, 1987), los testimonios contrapuestos en polémica en varios films 
realizados en los ochenta, las recreaciones absurdas de la historia nacional en el último film de Jorge Cedrón (TANGO, 1979) ${ }^{14}$ y las secuencias de registro de observación, que introducen lo no controlado en campo, indican que la transmisión de mensajes políticos no ha sido lineal. Por ello la distinción entre perspectiva formal y abierta propuesta por Plantinga resultó de utilidad para este caso. El cine documental argentino presenta un panorama más complejo a medida que indagamos en él.

El cine documental argentino del exilo contiene tanto films relacionados con el período revolucionario como obras que influirán en las realizaciones posteriores. Del mismo modo, para otras cinematografías de América Latina, el cine documental político de los setenta y ochenta lleva las marcas de una sociedad progresivamente radicalizada en busca de la revolución y, posteriormente, contemporizadora, con la voluntad de que se establezcan firmemente las bases de las instituciones democráticas, luego de violentas dictaduras. El caso del cine documental chileno del período es el más asimilable a su homónimo argentino. Films de certezas revolucionarias durante el gobierno de la Unidad Popular, bajo la presidencia de Salvador Allende, y en los primeros años de exilio luego del golpe. Films humanitarios de denuncia en la última etapa del exilio y los años de la transición democrática. ${ }^{15}$ Es decir, no es posible considerar al documental argentino como un caso único en el período, aunque la cantidad y relevancia de producciones superara ampliamente la de otros países de la región (Bolivia, Paraguay y Uruguay, por ejemplo).

Por último, la metodología de análisis resultó útil para indagar en los procedimientos estéticos de las diversas obras sin dejar de atender a los contenidos políticos de las mismas. Si bien no se considera que pueda ser aplicada tal cual utilizando las mismas categorías de análisis a otros períodos o vertientes documentales, su punto de partida brinda elementos para estudios que se propongan destacar continuidades y rupturas formales y temáticas entre films documentales dentro de un mismo conjunto (entiéndase: biográficos, etnográficos, sobre arte pictórico, musicales, etc.). Asimismo, los estudios sociales pueden brindar el marco que resultó la base de este análisis. Aunque el riesgo siempre está latente: encontrar en las películas lo que previamente habíamos

\footnotetext{
${ }^{14}$ Jorge Cedrón, luego de radicarse en París, filmó su última película, Tango (1979).

${ }^{15}$ Estudios profundos del cine documental chileno del período pueden encontrarse en MOUESCA (1988) y PICK (1984 y 1997).
} 
puesto en ellas o hablar de un período cinematográfico a través de textos históricos y políticos. Traté de conjurar tal tentación, yendo del análisis de los documentales hacia la sociedad. Analizando qué decían efectivamente los films, y cómo lo hacían, sin rescatar solamente aquello que iba en línea con lo caracterizado por los estudios históricos. Esfuerzo realizado que bien podría ser ensayado para hacer esa historia del cine documental argentino aún no escrita.

\section{Referências}

APREA, Gustavo. El cine político como memoria de la dictadura. In: SARTORA, Josefina RIVAL, Silvina (Eds.). Imágenes de lo real: la representación de lo político en el documental argentino. Buenos Aires: Libraria, 2007.

BURTON, Julianne. Toward a history of social documentary in Latin America. In: BURTON, Julianne (Comp.). The social documentary in Latin America. Pittsburgh: University of Pittsburgh Press, 1990.

CALVEIRO, Pilar. Poder y desaparición: los campos de concentración en Argentina. Buenos Aires: Colihue, 2001.

CALVEIRO, Pilar. Política y/o violencia. Buenos Aires: Norma, 2005.

CHANAN, Michael. Politics of documentary. London: British Film Institute, 2007.

CHANAN, Michael. El documental y el espacio público. In: CATALÀ, Josep María; CERDÁN , Josetxo (Eds.). Después de lo real. Valencia: Archivos de la Filmoteca, Instituto Valenciano de Cinematografía, v. 1, p.57-58, 2007/2008.

CHANAN, Michael. El documental político después de la Guerra Fría. Comunicación y Medios, Santiago de Chile: Instituto de la Comunicación e Imagen, Universidad de Chile n.24, 2011. [Dossie: Estudios sobre cine en América Latina].

CRENZEL, Emilio. La historia política del nunca más: la memoria de las desapariciones en la Argentina. Buenos Aires: Siglo XXI, 2008. 
ELENA, Alberto; LÓPEZ, Marina Díaz. The cinema of Latin America. New York: Wallflower Press, 2004.

FLORES, Silvana. El nuevo cine latinoamericano y su dimensión continental: regionalismo e integración cinematográfica. Buenos Aires: Imago Mundi, 2013.

FRANCO, Marina. El exilio: Argentinos en Francia durante la dictadura. Buenos Aires: Siglo XXI, 2008.

GAINES, Jane. Political Mimesis. In: GAINES, Jane; RENOV, Michael(Eds.). Collecting visible evidence. Minneapolis: University of Minnesota Press, 1999.

GETINO, Octavio; VELLEGGIA ,Susana. El cine de las historias de la revolución. Buenos Aires: Altamira, 2002.

GIUSSANI, Pablo. Los días de Alfonsín. Buenos Aires: Legasa, 1986.

JENSEN, Silvina. Los exiliados: La lucha por los derechos humanos durante la dictadura. Buenos Aires: Editorial Sudamericana, 2010.

JENSEN, Silvina. Exilio e historia reciente: avances y perspectivas de un campo en construcción. Revista Aletheia, La Plata, v. 1, n.2, mayo, 2011.

JENSEN, Silvina; YANKELEVICH ,Pablo. Exilios: Destinos y experiencias bajo la dictadura militar. Buenos Aires: Del Zorzal, 2007.

KAHANA, Jonathan. Intelligence work: the politics of American documentary. New York: Columbia University Press, 2008.

LAQUEUR, Thomas. Bodies, Details, and the Humanitarian Narrative. In: HUNT Lynn (Ed.), The new cultural history. Los Angeles: University of California Press, 1996.

LECHNER, Norbert. Los patios interiores de la democracia. Santiago de Chile: Flacso, 1988.

LESGART, Cecilia. Itinerarios hacia la democracia. Una tendencia de la izquierda intelectual argentina en el exilio mexicano. In: DEVOTO, Fernando; PAGANO, Nora (Eds.), La historiografía académica y la historiografía militante en Argentina y Uruguay. Buenos Aires: Biblos, 2004.

LONGONI, Ana. Traiciones: la figura del traidor en los relatos acerca de los sobrevivientes de la represión. Buenos Aires: Norma, 2007. 
MARKARIAN, Vania. De la lógica revolucionaria a las razones humanitarias: Los exiliados uruguayos y las redes transnacionales de derechos humanos. Revista Cuadernos del CLAEH, n.89, Montevideo, 2004.

MARKARIAN, Vania. El 68 uruguayo: el movimiento estudiantil entre molotovs y música beat. Bernal: Universidad Nacional de Quilmes, 2012.

MARTIN, Michael. New latin american cinema. Detroit: Wayne State University Press, 1997.

MESTMAN, Mariano. Estrategia audiovisual y trasvasamiento generacional. Cine Liberación y el Movimiento Peronista. In: SARTORA ,Josefina; RIVAL Silvina (Eds.), Imágenes de lo real: La representación de lo político en el documental argentino. Buenos Aires: Libraria, 2007.

MOUESCA, Jacqueline. Plano secuencia de la memoria de Chile, veinticinco años de cine chileno [1960-1985]. Madrid: Ediciones del Litoral, 1988.

NICHOLS, Bill. La representación de la realidad: cuestiones y conceptos sobre el documental. Barcelona: Paidós, 1997.

OBERTI, Alejandra; PITTALUGA, Roberto. Memorias en montaje: escrituras de la militancia y pensamientos sobre la historia. Santa Fe: María Muratore Ediciones, 2012.

OLLIER, María Matilde. De la revolución a la democracia: cambios privados, públicos y políticos de la izquierda argentina. Buenos Aires: Siglo XXI, 2009.

PARANAGUÁ, Paulo Antonio. Cine documental en América Latina. Madrid: Cátedrstival de Málaga, 2003.

PICK, Zuzana. La imagen cinematográfica y la representación de la realidad. In: ZUZANA Picky VALJALO, David (Comps.), 10 años de cine chileno 1973/1983. Revista Literatura chilena, creación y crítica, n. 27, enero/marzo, California, 1984.

PICK, Zuzana. The new Latin American Cinema: a continental Project. Texas: University of Texas Press, 1993.

PIEDRAS, Pablo. Cine político y social: un acercamiento a sus categorías a través de sus debates y teorías. In: LUSNICH, Ana Laura; PIEDRAS,Pablo. Una historia del cine político y social en Argentina: formas, estilos y registros. Vol.1 (1896-1969). Buenos Aires: Editorial Nueva Librería, 2009. 
PLANTINGA, Carl. Rhetoric and representation in nonfiction film. Cambridge: Cambridge University Press, 1997.

POZZI, Pablo; PÉREZ, Claudio. Por el camino del Che: Las guerrillas latinoamericanas.19591990. Imago Mundi: Buenos Aires, 2012.

SCHUMANN, Peter. Historia del cine latinoamericano. Buenos Aires: Legasa, 1988.

VEZZETTI, Hugo. Sobre la violencia revolucionaria: memorias y olvidos. Buenos Aires: Siglo XXI, 2009.

WAUGH, Thomas. Show us life: Toward a history and aesthetics of the committed documentary. Metuchen; New Jersey; London: The Scarecrow Press, 1984.

WINSTON, Brian. Claiming the Real: the griersonian documentary and its legitimations. London: British Film Institute, 1995.

YANKELEVICH, Pablo. Exilio y dictadura. In: LIDA, Clara; CRESPO, Horacio; YANKELEVICH , Pablo (Comps.). Argentina, 1976: estudios en torno al golpe de Estado. México: El Colegio de México, 2007.

ZIMMERMANN, Patricia. States of emergency: documentaries, wars, democracies. Minneapolis: University of Minnesota Press, 2000. 